\title{
The river as an element of urban composition
}

\author{
Adam Rybka ${ }^{1, *}$, Rafat Mazur ${ }^{2}$ \\ ${ }^{1}$ Department of Town Planning and Architecture, The Faculty of Civil and Environmental \\ Engineering and Architecture, Rzeszów University of Technology, al. Powstańców Warszawy 12, \\ 35-959 Rzeszów, Poland \\ ${ }^{2}$ Department of Town Planning and Architecture, The Faculty of Civil and Environmental \\ Engineering and Architecture, Rzeszów University of Technology, al. Powstańców Warszawy 12, \\ 35-959 Rzeszów, Poland
}

\begin{abstract}
Cities often owe their existence to rivers; however, when cities begin to develop, the river turns into a barrier whose crossing becomes one of the more important engineering issues in municipal infrastructure. As a part of nature, a river significantly influences the form of a city. Its development can, in turn, also impact the shape of the river. It becomes an element of urban composition. This mutual dependency is a key problem in spatial planning. Finding the right balance between the natural character of the river, and the introduction of city structures into its course, leads to the creation of a balanced space, naturally utilized by city dwellers.

The article analyses examples, which illustrate the relationship between a river and the city, with a particular look at Warsaw, where this relationship has undergone a huge transformation since the beginning of the $21 \mathrm{st}$ century.
\end{abstract}

\section{Introduction}

\subsection{Analysis of the problem}

The affect of a river on urban space constitutes a contradiction. For many obvious reasons a river can be the main reason for the creation of a city, while at the same time acting as a powerful borderline within its structures. Building crossings, drying areas for development, regulating its course, as well as protection against flooding are huge engineering endeavours. The incongruity of man versus nature always accompanies architectural space. When building a house, a person tries to isolate themselves from nature, while at the same time trying to remain close to it for the purpose of survival. A similar scenario concerns a city that is developing on a river, although the scale is much larger. The city needs the river to function, but also has to deal with all the consequences of its presence.

The ambivalent character under which rivers function in cities can also be seen within their urban composition. Excluding aspects of nature's utility, such as access to water, natural fortifications and convenient communication and transport, it is worth noting that the presence of water in the landscape provides people with a lot of positive emotion. A

* Corresponding author: $\underline{\text { akbyr@prz.edu.pl }}$ 
river, as well as other water bodies, are places where people want to spend time. The creation of recreational areas was often connected to the presence of water in the landscape. Despite the fact that the aesthetic question has not seen an unequivocal answer over the last few hundred years, a space with a body of water, and an abundance of surrounding nature, constitutes an area, which acts positively on the people who reside there. According to American philosopher Dennis Dutton, universal aesthetic criteria were shaped by the Pleistocene epoch [1]. Their main goal is to guarantee survival of the species. Research entitled "The people's choice. Most wanted \& most unwanted," carried out by Vitaly Komar and Alex Melamid, clearly shows that irrespective of the geographical latitude, people prefer a green environment with a river or lake.

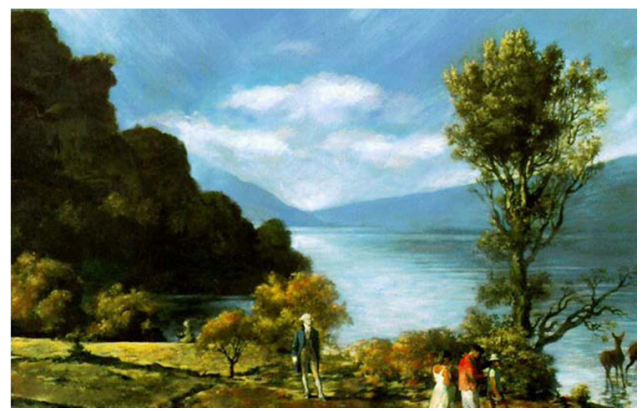

Fig. 1. United States: Most wanted painting. Authors: Vitaly Komar, Alex Melamid (source: www.artnet.com).

The basic necessities which man requires to survive, and the resulting aesthetic needs, have led to the building of settlements in the vicinity of rivers. A river usually becomes an important element, which cements the city plan. If correctly utilized, the river - a barrier that has to be crossed - is also an element of urban composition that is shaped depending on the needs of city dwellers. As with any natural building material, a flowing water system can also be used to create architectural space [2].

\subsection{The condition of analysis}

A lot of literature exists on the role a river plays in the city. Analyses of its influence on urban structures accompany nearly every publication which concerns urban space. The river often figures in literature as an element of the city. Ancient and Renaissance architectural treatise saw it as a fundamental element of nature, which allowed for the development of cities. The assumption that a city should lie beside a river was one of the most important aspects of an ideal city. Wojciech Kosiński analyzed the aesthetic value of rivers in historical cities in his article entitled "Preliminary research upon the problem: beauty of the city" [3].

When dealing with the city-river relationship as an element of urban composition, one must also mention a work entitled "Elementy kompozycji urbanistycznej" [Ed. Elements of urban composition] by Kazimierz Wejchert. [4] For him the river was primarily a beautiful "floor" for the urban interior. It is also worth drawing on the work of Juliusz Żórawski, entitled "Siatka prostych" [Ed. The network of straight (lines)], published a few dozen years after his death. His final thoughts focused on the relationship of architectural space with the world of nature [5].

In order to look at the wider issue, it is also necessary to research publications on aesthetics. The aforementioned author Dennis Dutton links mankind's aesthetic tastes with the theory of evolution in his revealing book entitled "The Art Instinct." 
There are also many sociological publications concerning rivers in cities. The tendency for cities to open up to rivers in the post-industrial era means that the question of how the river functions within a city is now becoming an interdisciplinary issue.

At Warsaw universities, a large amount of studies on the Vistula and its significance for the city have been made in recent years by Janusz Skalski [6].

\subsection{Methods of analysis}

The river can be studied as an element of urban composition via a presentation and analysis of specific processes, which the city undergoes in relation to it. Constant changes seen in the city are often connected to the functioning of its river. The processes that we will present in this article are universal and concern many cities. A great example that can be used to illustrate this issue is the city of Warsaw, which has seen a massive transformation of the relationship with its river since the beginning of the 21 century.

\section{River and City - processes}

\subsection{Forming the riverbank}

Changing the course of the river Turia in Valencia is an interesting example of the river as an element of urban composition. One that can be transformed to suit the needs of its users, or for aesthetic value just as former fortifications or blocked traffic ways have been changed in the past. A flood, which took place in 1957, caused massive damage to the city. This led city authorities to carry out an engineering project, according to which the river course was moved outside of the city centre. The old course of the Turia river constituted the main compositional axis for the city. The utilization of the former water course for park space meant that the city gained a lot of recreational space in its centre.

A similar feat, although much smaller in scale, was carried out in Poznan in the 1960s. A floodplain called the Chwaliszewski meander was filled in causing the Warta river to bypass the city centre. The project was drawn up in the first half of the 20th century. Changing the water course of a river is not a new phenomenon in engineering. Such a project was ordered by the Florentine Republic, for example, at the start of the 16th century. It was drawn up with the help of Leonardo da Vinci. The need for it was dictated by strategic and political issues. It was not realized however. Although, if the Arno river had changed its course, history would also be significantly changed. In the 19th century a pioneering endeavour took place in the US, where the course of the Chicago River was reversed to avoid waste, which was poisoning the inhabitants of this dynamically developing metropolis, being washed into Lake Michigan. The project involved the construction of a canal leading to the Des Pleines River. 


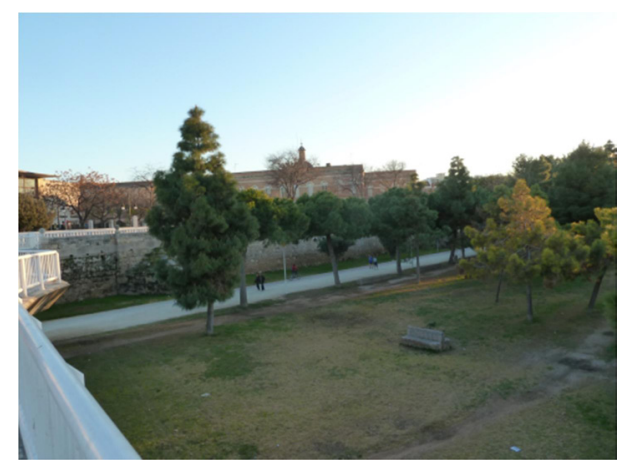

Fig. 2. Development of the Turia watercourse in Valencia (photo. A. Rybka).

Changing the watercourse of rivers was also key to the development of Warsaw. In the $18^{\text {th }}$ century the city had a dense network of rivers and lakes. Warsaw's modern form is the result of manmade changes, as well as its historical hydrographical network. The streets that lead from the embankment to the Vistula river are usually located on the site of former watercourses, which were channelled in order to protect against flooding and to clear new areas for development. In a research project about Warsaw squares, carried out for the Warszawa w Budowie [Ed. Warsaw under construction] festival in 2017, Paweł Brylski talks about the shape of Three Crosses Square in Warsaw. The square owes its form to the Zurawka river, which flowed into Warsaw. A statue of St. John Nepomuk, the patron saint that protects against flooding and drowning, is a lasting reminder of the problems once caused by the Zurawka river. The erection of many statues glorifying this saint indicate his cult status and the enormous danger posed by rivers in the past [6].

\subsection{Overcoming the borderline}

In most cities the river constitutes a significant borderline. Depending on the number of crossings, it can, however, be assimilated into city structures. Wrocław constitutes such an example. Here, a large number of bridges guarantee efficient communication, thus integrating different parts of the city. In the case of rivers with wide courses such integration is not possible. This is due to the large distances which need to be covered in order to cross it. Cities are usually divided into two parts, which are defined by the largest river. Each part of the city usually has a specific identity and history. An example of this can be seen in Buda and Pest, Bielsko and Biała, and in Paris and London, where there is a clear north-south divide. Such a significant divide can also be seen in Warsaw, where the east bank of the river, called Praga, constituted a separate city. The Vistula river, together with adjoining flood land, creates a wide borderline. Crossing this area by car, tram or train takes a long time making the crossing noticeable for the passenger. The size of the river means that it cannot disappear from the consciousness of residents who utilize both parts of the city.

A part-research part-artistic project called "Tuning Warsaw", put together by Dutch architect Monnik and architect and artist Michał Jońca in 2014, identified a specific phenomenon that would be seen in Warsaw after the opening of the second underground line, which required the construction of a tunnel under the Vistula River. The authors of a book entitled, "The Make Yourself at Home Guide to Warsaw," published after the opening of the underground line across the river, wrote: "since the second underground line was built, a groundbreaking possibility has appeared to walk on both sides of the city without 
seeing the river [...]." Jońca envisioned the creation of a plan of Warsaw without the Vistula River, as a new method of perceiving the city [7].

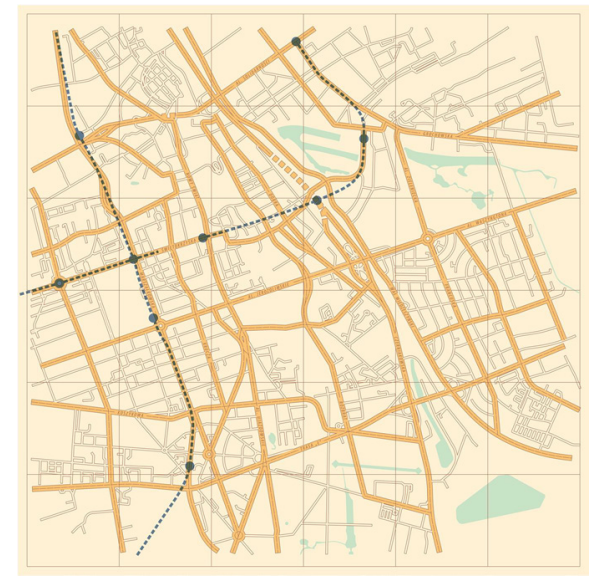

Fig. 3. Riverless Warsaw - author: Michał Jońca (archive of Michal Jońca).

A map without the Vistula River awakens much emotion in people who know and love the city. Without the river it loses its identity. Jońca's work shows that the borderline, which is the river, is an inseparable element of Warsaw. This is despite the fact that crossing it requires a certain financial burden and that according to this new vision, the city would be better communicated. However, erasing the river would cause the loss of one of the most important elements of urban composition.

\subsection{Facing the river}

The cities of western Poland and Europe have regulated rivers, which means that they have been integrated to suit the development in a given area. Rivers create city interiors reminiscent of representational streets. Many crossings are built across small rivers. They are no longer real barriers and enrich the urban landscape. However, cities in central Poland were mostly built at a safe distance from large rivers in order to safeguard inhabitants against flooding. A characteristic of many Polish cities including Sandomierz, Płock and Warsaw was that they were built on an embankment. This meant that for a few hundred years they were turned away from the river.

In the second half of the 20th century the Vistula was a separate space. It was practically cut off from Warsaw. Architects and Warsaw residents looked upon other European cities, where rivers were the centre of urban life, with envy. Ideas to develop the banks of the river were not realized. Although such plans were already being drawn up in 1945 by Maciej Nowicki in the Biuro Odbudowy Stolicy [ed. Office for the Redevelopment of Warsaw]. The Vistula and its natural surroundings remained practically untouched until the 21 st century. This is especially the case for the west bank of the river. There is an anecdote, according to which a delegation of Japanese urban planners, when presented with a view of the west bank of the river, asked their hosts who designed such a lovely river bank. Years of neglect created a perverse effect, which saw the capital of a European country cut in half by huge areas of unique natural and environmental value. This phenomenon was highlighted by film director, Andrzej Wajda, who urged spatial planners to preserve the natural form of the west bank of the river, while at the same time urging 
investments that would integrate residents with the Vistula's easterly shores. This was congruent with ideas tabled by urban planners at the turn of the 20th and 21 st century.

The first significant step to bringing the Vistula river - at that time cut off by a dual carriageway - closer to Warsaw's residents, was the construction of a tunnel in the central part of the city, and the building of the Świętokrzyski bridge (an extension of Tamka street), launched in 2001. The tunnel would run alongside the river. It was to be $900 \mathrm{~m}$ long. The bridge on the other hand, did not play an important role in the city's communications network, but it brought the other side of the river closer for cyclists and pedestrians. The realization of the tunnel, even though controversial at the time, meant that residents could, for the first time since the appearance of mass automotive transport, freely reach the Vistula River. The investment coincided with the opening of the Warsaw University Library designed by Marek Budzyński. This unique building became a catalyst for changes in the whole area. The Copernicus Science Centre was built on top of the tunnel. Measures were also taken to set up temporary HQs for the Museum of Modern Art and the Academy of Fine Arts in the vicinity of the new investments. City authorities held a competition to develop the west bank of the Vistula. At the same time, the river bank, which up till now had remained neglected, started being visited by an increasing number of people. It finally saw many temporary high quality grassroots investments. Finally, Warsaw's cultural life moved to the riverbank. Theatre plays, concerts and lectures were held there. In 2017, local authorities completed the Vistula boulevards in Warsaw directly below the Old Town and Krakowskie Przedmiescie, thus creating a cohesive structure with a representative part of the city.

Simultaneously to investments, which drew inhabitants to Vistula's west bank, the east bank of the river was cleaned up. Its beaches were cleared and tourist trails created within the woodlands near the riverbank. Residents and tourists started to visit the other side of the river more often. National Geographic rated the Warsaw beach on the east bank of the river as one of the best urban beaches in the world. After a mere 20 years of investment and grassroots initiatives by city activists, one can conclude that the city has turned back towards the river and is utilizing its natural potential with increasing success.

\subsection{Inhabiting the river}

Water basins are an area, which can be party settled. Functioning residential complexes made up of floating homes in Amsterdam, Hamburg and Copenhagen prove this can be an alternative to traditional habitation on land. Most of the time, these are housing complexes located in cities with large canal networks or access to the sea. Rivers of an appropriate size can also serve as living space.

Floating homes are realized in Poland on a smaller scale, although a large water surface in many cities means that the these types of projects may increase in number. The first floating home was built in Wrocław in 2013. Similar projects have since appeared in Gdańsk, Bydgoszcz and Warsaw. Interest in the subject means that cities are preparing infrastructure to suit floating objects. A good example of this is Czerniakowski Port in Warsaw. It is located near the city centre and is an attractive area to move to. An increasing number of people are deciding to live there. In the last few years specially prepared spots in the port have filled up with floating homes. This is a clear signal for city authorities that such living conditions should be facilitated for people. 


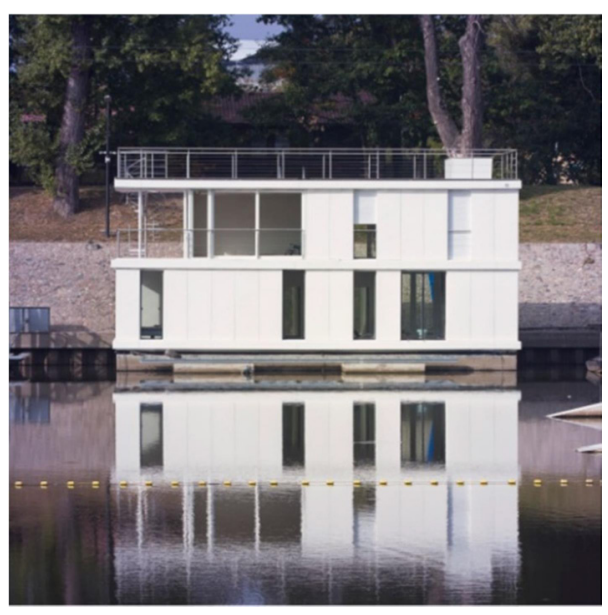

Fig. 4. A floating home in Port Czerniakowski in Warsaw - project by Mai Bui and Rafał Mazur (photo. M. Czerski).

Developers are also becoming interested in this alternative way of living. A residential complex made up of floating homes is planned for construction in Parski Port. It is worth noting that this is not a new idea. Floating objects filled the river in 18th century Warsaw.

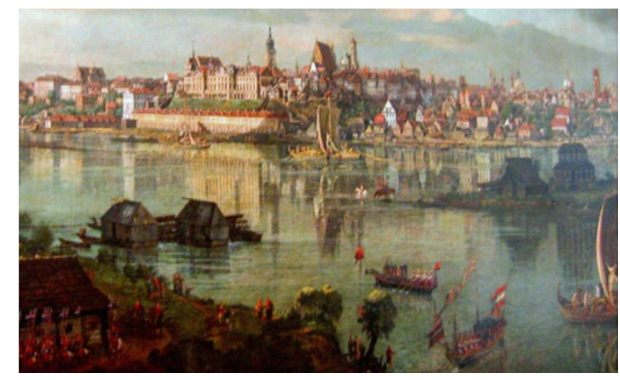

Fig. 5. Fragment panoramy Warszawy z 1770 roku - Bernardo Bellotto Canaletto (source: commons.wikimedia.org).

\section{Conclusion}

The processes presented in the article, pertaining to the river-city relationship, show various planning issues connected to the development of rivers and the areas surrounding them. The first deals with influencing the natural aspects of a river and the possibility of changing its course. Depending on its role and requirement, the river can become a tool, which correctly shaped, may better serve city inhabitants. The second process is connected with the river as a barrier and the need to overcome it. It is worth noting, however, that despite the fact that rivers constitute borderlines in cities, their total elimination from everyday life would result in a worsening of the quality of life experienced by city dwellers. The third process presents the gradual return of the city to the river in the 21 st century. The utilization of the natural potential of the Vistula River and neglect of previous decades, have led to the retention of a unique space in a city with more than one million inhabitants. The last process discussed indicates the possibilities of the river as an untapped source for the construction of floating 
objects. The location of rivers in city centres guarantees a very attractive additional space to live in, as well as other functions needed in the city.

All the processes discussed in the article show that rivers should not be treated solely as fragments of attractive scenery, but that they are elements of urban composition, which should be appropriately taken into consideration when putting together spatial planning projects. The incongruity, which lies at the basis of the city-river relationship, indicates that an appropriate balance should be found between the needs of nature and mankind. The river cannot impede in the everyday functioning of life in a city. However, excessive interference in the functioning of a river may bring losses to the city. As the example of Warsaw shows, a lack of intervention in the river's form may led to the creation of a unique space, which is able to fulfil the recreational needs of every city dweller.

\section{References}

1. D. Dutton, The art instinct (Oxford 2009) p. 19

2. B. Twaróg, Z. Kęsek, JCEFA, 32 (2015) p. 554

3. W. Kosiński, Przestrzeń i FORMA, 10 (2008)

4. K. Wejchert, Elementy kompozycji urbanistycznej (Warsaw, 2016)

5. J. Żórawski, Siatka prostych (Krakow, 2014)

6. J. Skalski, Ocena walorów krajobrazu w procesie postrzegania na podstawie krajobrazu doliny Wisty w Warszawie (Warsaw, 2011)

7. https://placewarszawy.pl/pl/plac-trzech-krzyzy/plac/22

8. Monnik, The Make Yourself at Home Guide to Warsaw (Warsaw, 2015) p. 254 